\title{
Can We Discern the Effect of Globalization on Income Distribution? Evidence from Household Surveys
}

\author{
Branko Milanovic
}

\begin{abstract}
New data derived directly from household surveys are used to examine the effects of globalization on income distribution in poor and rich countries. The article looks at the impact of openness (proxied by the ratio of trade to GDP) and of direct foreign investment on relative income shares across the entire income distribution. It finds strong evidence that at low average income levels, the income share of the poor is smaller in countries that are more open to trade. As national income levels rise, the incomes of the poor and the middle class rise relative to the income of the rich. The article explains why using the trade to GDP ratio in purchasing power parity terms, as favored by some analysts, is inappropriate in studies of the effect of trade on income distribution.
\end{abstract}

The effect of globalization on income inequality has received widespread attention in the past decade. Most of it was concentrated on the effects on wage and income inequality in the United States, Western Europe, and other rich countries (Slaughter and Swagel 1997; Dluhosch 1998; Schott 2001; Lejour and Tang 1999). A second strand of the literature has focused on how globalization affects world income distribution through differences in mean per capita growth rates (Milanovic 2004; Milanovic and Yitzhaki 2002; Melchior and others 2000; Schultz 1998; Sala-i-Martin 2002).

Only recently has there been more interest in how globalization affects income distribution within developing economies (Cornia and Kiiski 2002; Lustig and

Branko Milanovic is lead economist in the Development Research Group at the World Bank and senior associate at the Carnegie Endowment for International Peace; his email addresses are bmilanovic@worldbank.org and bmilanovic@ceip.org. He is grateful to Dimitri Kaltsas, Gouthami Padam, and Prem Sangraula for excellent research assistance. The article has been much improved thanks to the comments of Jaime de Melo, Richard Freeman, James K. Galbraith, Aart Kraay, Martin Ravallion, Peter Rundell, Alan Winters, three anonymous referees, and two anonymous editorial board members. The author is also grateful for comments and suggestions from participants at the Conference on Globalization and Inequality at the Brookings Institution in Washington, D.C., in June 2002; the Massachusetts Avenue Development Seminar at the Center for Global Development in Washington, D.C., in November 2003; and the Conference on Globalization, Poverty, and Inequality at the University of Utah in November 2004. The article was written as part of research project 857-25 financed by a World Bank Research Grant.

THE WORLD BANK ECONOMIC REVIEW, VOL. 19, NO. 1, pp. 21-44

doi:10.1093/wber/lhi003

(C) The Author 2005. Published by Oxford University Press on behalf of the International

Bank for Reconstruction and Development / THE WORLD BANK. All rights reserved. For permissions, please e-mail: journals.permissions@oupjournals.org. 
Kanbur 1999; Ravallion 2001; Galbraith and Kum 2002). There are theoretical models of how trade affects income distribution (Wood 1994, 2000; Benarroch and Gaisford 1997; Kremer and Maskin 2003). ${ }^{1}$ Detailed empirical analyses of the effects of economic change, including market reforms and increased international integration, on within-country income distribution are essentially limited to Latin America, however. Harrison and Hanson (1999) and Robertson (2000) study wage inequality in the wake of Mexican trade reforms. Beyer and others (1999) look at a similar issue in Chile. Arbache (1999) studies the effect of market liberalization on sectoral wage dispersion in Brazil. Behrman and others (2003) assess the impact of various policy changes (including trade liberalization and capital account opening) on wage differentials in Latin American countries.

But there are relatively few studies of the impact of openness on income distribution in both poor and rich countries, which is the objective of this article. ${ }^{2}$ Two recent studies by World Bank researchers (Lundberg and Squire 2003; Dollar and Kraay 2002) look at the relationship between openness and growth and find conflicting evidence on the relationship between openness and inequality. Lundberg and Squire $(1999,2003)$ consider growth and inequality to be determined simultaneously. They find that openness, measured by the SachsWarner (0-1) indicator, has either no effect or a mild negative effect on inequality. ${ }^{3}$ Barro (2000) and Ravallion (2001) find statistically significant nonlinearity in the relationship between openness and inequality, with openness associated with increased inequality in poor countries. In a somewhat different twist, Spilimbergo and others (1999), controlling for countries' endowments in skilled labor, capital, and land, find that openness reduces inequality in capital-rich countries while increasing inequality in countries with abundant skilled labor. They argue that the effect in capital-rich countries is driven by the reduction of capital rents once domestic capital markets open up, whereas the effect in laborrich countries is consistent with the Heckscher-Ohlin framework.

Dollar and Kraay $(2000,2002)$ reach a different conclusion. Using an unbalanced panel covering the same period and similar countries as Lundberg and Squire (2003), they find that openness (defined as exports plus imports as a share of GDP ${ }^{4}$ is positively associated with per capita income growth and that this effect is the same for the bottom income quintile as for the mean-trade has no systematic impact on inequality. Because trade is good for growth, the effects across all income groups are positive and the same-where the "same" means that each decile's gain is proportional to its initial income. (The rich benefit more in absolute but not in relative terms.) In a similar vein, Birdsall and

1. For a recent review of the evidence on the relationship between trade and poverty and its compatibility with expectations based on theory of international trade, see Winters and others (2004).

2. The terms openness and globalization are used interchangeably in this article.

3. They also find that when growth and inequality are determined simultaneously, openness is a tradeoff variable: Its effect is positive for growth and negative for equality.

4. With GDP measured in PPP terms-a feature with important implications, as explained later. 
Londono $(1997,1998)$ report no differences in growth in income between the poorest and other quintiles due to trade variables, although initial distributions of land and education do matter. Finally, Li and others (1998), in a sensitivity run of their main model, use the ratio of exports to GDP (a proxy for openness) as an explanatory variable for the Gini coefficient. They also find no statistically significant effect of openness on the Gini coefficient.

These different findings (summarized in table 1) have generated intense discussion. Dollar and Kraay (2000) address some empirical and methodological differences between their study and that of Lundberg and Squire (1999). A recent study by Ravallion (2004) attempts to uncover the source of the differences in results and to "reconcile" their findings. He is doubtful about both types of findings because the studies depend on fairly noisy data and work with averages only. According to Ravallion, generalizations are difficult because the heterogeneity in countries' underlying conditions is too great.

In any case, cross-country studies yield inconsistent results on the effects of openness on inequality. On the one side, Li and others (1998), Birdsall and Londono (1998), and Dollar and Kraay $(2001,2002)$ find that openness has no systematic and significant effect on inequality. On the other side, Lundberg and Squire (1999), Barro (2000), and Ravallion (2001) find that openness has a negative effect on equality in poor countries and that in some of the formulations it has a negative effect on the real income of the poor as well. The conclusions run nearly the full gamut, from openness reducing the real income of the poor to openness raising the income of the poor proportionately less than the income of the rich to raising both the same in relative terms. Note, however, that there are no results that show openness reducing inequality, that is, raising the real incomes of the poor proportionately more than the incomes of the rich-let alone raising the absolute incomes of the poor by more.

\section{The New Database}

This article provides additional empirical evidence on how globalization affects income distribution in developed and developing economies, using the newly developed database, World Income Distribution (WYD) (available online at www.worldbank.org/research/inequality/data). The data are drawn almost entirely from household-level surveys, giving the database two main advantages over earlier income distribution databases such as that of Deininger and Squire (1997) and WIDER (2004). ${ }^{5}$ One is the ability to define welfare aggregates as well as recipient units consistently across countries and time, and the other is the

5. Data for about two-thirds of country/years are calculated directly from household surveys, a much higher proportion than in other databases (Deininger and Squire 1997 or WIDER 2004), which depend heavily on published, not necessarily mutually consistent, sources. Additional details about the data sources and surveys are available in Milanovic (2004, chap. 9 and 10) and Milanovic (2002, appendix 1); the data are available online at www.worldbank.org/research/inequality/data. 
TABLE 1. Comparison of Various Studies of Openness and Inequality

\begin{tabular}{|c|c|c|c|c|c|}
\hline Study & Period & $\begin{array}{l}\text { Sample, Number of } \\
\text { Observations, and } \\
\text { Number of Countries }\end{array}$ & $\begin{array}{c}\text { Definition of Openness } \\
\text { Variable }\end{array}$ & $\begin{array}{l}\text { Welfare or Inequality } \\
\text { Measure (source of data) }\end{array}$ & $\begin{array}{l}\text { Effect of Openness } \\
\text { on Inequality }\end{array}$ \\
\hline Dollar and Kraay (2002) & 1960-99 & $\begin{array}{l}\text { Unbalanced panel; } \\
5 \text {-year intervals; } \\
285 \text { observations; } \\
92 \text { countries }\end{array}$ & Trade/GDP in PPP terms & $\begin{array}{l}\text { Income share of bottom } \\
\text { quintile (mostly WIDER 2004) }\end{array}$ & Insignificant \\
\hline Ravallion (2001) & 1960-94 & $\begin{array}{c}\text { Unbalanced panel; } \\
\text { 5-year intervals; } \\
159 \text { observations }\end{array}$ & $\begin{array}{l}\text { Export/GDP in } \\
\text { current dollars }\end{array}$ & $\begin{array}{l}\text { Gini from Deininger } \\
\text { and Squire (1997) }\end{array}$ & $\begin{array}{l}\text { Proinequality in poor } \\
\text { countries }\end{array}$ \\
\hline Barro (2000) & 1960-90 & $\begin{array}{l}\text { Balanced panel; } \\
\text { 10-year intervals; } \\
214 \text { observations }\end{array}$ & $\begin{array}{l}\text { Trade/GDP adjusted for } \\
\text { country size }\end{array}$ & $\begin{array}{l}\text { Gini from Deininger } \\
\text { and Squire (1997) }\end{array}$ & $\begin{array}{l}\text { Proinequality in poor } \\
\text { countries }\end{array}$ \\
\hline $\mathrm{Li}$ and others (1998) & 1960-94 & $\begin{array}{l}\text { Unbalanced panel; } \\
\text { 5-year intervals; } \\
159 \text { observations }\end{array}$ & $\begin{array}{l}\text { Export/GDP in current } \\
\text { dollars }\end{array}$ & $\begin{array}{l}\text { Gini from Deininger } \\
\text { and Squire (1997) }\end{array}$ & Insignificant \\
\hline
\end{tabular}

Source: Author's compilation. 
provision of information on income levels by deciles (or even finer partitions), which can end the reliance solely on such synthetic inequality measures as the Gini coefficient and the Theil index.

The ability to look at the entire distribution, at what is happening behind a change in one summary statistic, is crucial for getting a better grasp of the effects of globalization. WYD is very rich cross-sectionally. It includes 321 surveys with decile data for 95 countries in 1988 and 113 countries in 1993 and 1998. It covers only these three benchmark years, however. All incomes are expressed in international dollars (in purchasing power parity, Ppp, terms).

The WYD data cover more than 95 percent of world GDP income and around 90 percent of world population. Coverage is almost complete for all geographical regions except Africa. For Africa the 1998 data cover more than two-thirds of the population and income, although the proportion is smaller for the 1988 data.

\section{Channels of Influence on the Entire Income Distribution and Estimation Issues}

By definition, the absolute income level of the $i$ th decile in country $j$ at time $t$ can be written as a function of an inequality index $\left(I_{j t}\right)$ and mean income of the country $\left(m_{j t}\right){ }^{6}$

$$
y_{i j t}=f\left(I_{j t}, m_{j t}\right)
$$

The relative income of the $i$ th decile (normalized by the mean) is then ${ }^{7}$

$$
y_{i j t} / m_{j t}=g\left(I_{j t}\right)
$$

The level of the inequality index is then assumed to depend on the levels of the following variables:

- Two "standard" globalization variables: openness $\left(O P E N_{j t}\right)$, measured as the sum of exports and imports in the country's GDP, and direct foreign investment as a share of GDP $\left(D F I_{j t}\right)$;

- Financial depth $\left(F D_{j t}\right)$, the ratio of M2 to GDP, introduced on the assumption that greater financial depth should reduce the importance of the financial constraint to borrow for education purposes, and thus should help those who are talented but lack resources (see, for example, Li and others 1998); and

- An indicator of democracy $\left(D E M_{j t}\right)$, introduced on the assumption that democratization, through the median voter hypothesis, should lead to greater redistribution and a reduction in inequality (Milanovic 2000; literature review in Gradstein and Milanovic 2004).

6. Deciles go from the poorest, 1 , to the richest, 10 .

7. The movement from 1 to 2 implies the homogeneity assumption. 
The use of the trade to GDP ratio as a measure of globalization has been criticized-although in a somewhat different context-by several researchers (Rodrik 2000; Birdsall and Hamoudi 2002; Lubker and others 2002). There are two key critiques. First, although openness represents an outcome that governments cannot influence and not a policy, or choice, variable such as the tariff level, openness is often presented-implicitly at least-as a policy. The trade ratio may decline not because the country follows a more closed policy but, for example, because of balance of payments difficulties, as happened when the terms of trade for commodity producers collapsed in the early 1980s (Birdsall and Hamoudi 2002). A failure to consider this exogenous shock could result in falsely ascribing the growth slowdown in the 1980s to decreased "openness." Second, the trade to GDP ratio is often treated as a determinant of growth, whereas causality may run in the opposite direction, from growth to trade.

Both criticisms are valid, but they do not affect the use of openness as a variable to explain inequality, as is done here, where the concern is not with policies (with whether a country follows open policies or not) or with the growth-trade causality. Rather, the concern is solely with how a given level of trade-whether achieved through open or closed policies-affects the distribution of income. Openness is not taken to be a choice variable but is considered only for its possible impact on income distribution.

What of the other variables? Financial depth and democracy are not thought to be linked directly with globalization even though such a view could be plausibly entertained. For example, increased financial depth (increased monetization of the economy) can be regarded as proceeding directly from better integration of a country into the international economy, and democratization can be thought to occur in response to greater international exchanges. However, these two variables are used here as controls for the nonglobalizationrelated part of the influence on income distribution and as orthogonal to the globalization-proper variables. They are introduced primarily to avoid misspecification of the model.

In this formulation there is no role for income as an explanatory variable. The argument that income affects inequality and should be included on right side of the equation is based on some variant of the Kuznets-type relationship. Whether or not one subscribes to the Kuznets hypothesis, it is clear that income serves only as a proxy for several structural changes-the movement of labor (from agriculture, where income is more equally distributed, to industry, where it is less equally distributed), educational change (increasing share of highly skilled people and a decreasing education premium), or demographic change (increasing share of the elderly and rising social transfers). These structural changes are all associated with rising GDP per capita. Once the equation is solved for such structural correlates of income as financial deepening and democracy, income plays no additional independent role.

However, the possibility has to be taken into account that the globalization variables will have different effects on the share of a given decile depending on a 
country's level of development. The simple Stolper-Samuelson theorem implies that increased openness and direct foreign investment would benefit low-skilled workers in poor countries (for caveats and why this may be a special case, see Winters and others 2004, pp. 73 and 97). Thus, in poor countries the signs for the OPEN and DFI variables would be expected to be positive among the bottom deciles (increasing their income shares). In rich countries the situation would be the reverse. Openness would expose low-skilled workers to increased foreign competition, so the signs among the bottom deciles for the OPEN and DFI variables would be expected to be negative. The coefficients of the two globalization variables will therefore vary as a function of the income level of the country. Ideally, of course, the coefficients should vary as a function of the skill composition of each income decile and each country's income level. However, because the data do not include information on the individual composition of each decile or on the skill composition of people in each decile, the country's income level is interacted with the openness variable. Barro (2000), Ravallion (2001), and Dollar and Kraay (2002) have all used interaction between openness and income.

Thus the equation can be written (omitting time subscripts) for each decile:

$$
\begin{aligned}
y_{i j} / m_{j}= & \beta i_{0}+\beta i_{1} \mathrm{OPEN}_{j}+\beta i_{2} m_{j}+\beta i_{3}\left(\mathrm{OPEN}_{j}^{*} m_{j}\right)+\beta i_{4} D F I_{j} \\
& +\beta i_{5}\left(D F I_{j}^{*} m_{j}\right)+\Sigma_{k} \beta i_{k} X_{k}+e_{i j},
\end{aligned}
$$

where the $X$ 's stand for other controls. In the most parsimonious formulation these other controls are financial depth and democracy. The $\beta$ coefficients vary across deciles and are thus subscripted.

Ten pooled cross-section regressions-one for each income decile-with the same independent variables are run across all countries. Regressions such as equation 3 can be run independently (with one omitted) or as a simultaneous system (seemingly unrelated regressions) with a constraint. ${ }^{8}$ The constraint ensures that increases in the shares of some deciles are balanced by decreases in the shares of others. Because of likely autocorrelation of shares (within countries and across years), the regressions are run with robust (Huber/White) standard errors.

There are two additional problems: endogeneity and robustness of the results to the introduction of other variables. The endogeneity problem may plague both the openness and other right-side variables. Inequality might influence financial depth, democracy, or government spending (introduced later). To

8. If the slopes are assumed to be homogenous across countries and the intercepts are "fixed" (different between countries), a fixed-effect (FE) estimator could be used. If this estimator were used, it could be argued that the marginal effects of openness (and other explanatory variables) are the same across countries, so inequality could be determined (by varying the intercept) by other unobservable country-specific effects. This seems reasonable, but because the panel is very short (three observations only) and shares within countries change very slowly, most of the data variability is contained in crosssectional observations. Thus, the use of the FE estimator yields poor results. 
adjust in part for endogeneity, all right-side variables are calculated as five-year averages. There is also a substantive reason for that: to reflect the fact that openness or financial depth does not affect income distribution instantaneously. Endogeneity is also addressed more fully by instrumenting the possibly endogenous variables by their lagged values and other instruments and by using a generalized method of moments (GMM) estimator whose efficiency properties are superior to those of the traditional instrumental variable/two-stage least squares estimators.

The robustness of the results can be questioned because the right-side variables may not include all relevant variables that can affect income shares. As a check on the robustness of the results, the parsimonious formulation is extended by adding government spending as a share of GDP and the real rate of interest. Government spending is expected to be propoor, and the real interest rate, due to the typically high concentration of capital assets in the hands of the incomerich, is expected to be prorich. Control variables are added for regional effects as well because one of the strong results of the inequality literature is that there are regional patterns in income distribution (Latin American and African countries tend ceteris paribus to have more unequal income distributions and Asian countries more equal; see Higgins and Williamson 1999; Fields 2001; Milanovic 1994). ${ }^{9}$ Broadening the range of the control variables also addresses another potential source of endogeneity: having another omitted variable jointly determine inequality and the right-side variables. Increasing the number of controls on the right side tends to cover most of the bases for such an effect.

\section{Descriptive Statistics}

Before globalization and other macro-variables are linked to changes in income distribution, the variables need to be defined more precisely. Income distribution is based on data on annual per capita incomes in pPp dollars of each decile from the 321 surveys and 129 countries in total (with 82 countries being a balanced panel) for the benchmark years 1988, 1993, and 1998. Each decile contains 10 percent of individuals, not households. The dependent variable is defined as the ratio between decile mean income and country mean income.

All right-side variables are calculated as averages over five-year periods rather than single values for 1988, 1993, and 1998, for two reasons. First, the distribution data are only benchmarked in 1988, 1993, and 1998. The surveys used to calculate the decile data might have been conducted before or after the benchmark year (say, 1986 or 1989 rather than 1988). ${ }^{10}$ Thus the "averaging" for the dependent variable is accompanied by a similar averaging of the controls.

9. This point was made by an anonymous referee.

10. Overall, however, more than 70 percent of the surveys are within a year of the benchmark, and more than 90 percent of surveys are within two years of the benchmark. 
Second, even if all the surveys were conducted the same year, there would be some advantage in relating changes in income shares to several years' average share of exports and imports in GDP. This is done to avoid having the results swamped by noise-very short-run changes that cannot have much influence on a sluggish variable like income distribution. Thus openness that is associated with income distribution around 1988 is taken as the average of exports and imports to GDP during the five-year period ending in 1988. The same is done for income distribution in 1993 and 1998. Identical calculations are done for other right-side variables.

Mean-normalized average incomes were calculated for each decile in 1988, 1993, and 1998 (table 2). For example, in 1988 the bottom decile's income was 30.7 percent of the mean calculated across all countries and 30.3 percent of the mean calculated across the common-sample countries. ${ }^{11}$ By 1993 the bottom decile's income had fallen to 23.5 percent of the mean for all countries and 24.4 percent of the mean for the common-sample countries. By 1998 it had declined even further, to 23.3 percent of the mean for both groups. Between 1988 and 1993 the relative incomes of the bottom eight deciles declined-with the largest decline among the poorest deciles-and the relative income of the top two deciles rose, with the greatest increase among the very top. The situation changed between 1993 and 1998, when deciles two through seven gained, whereas the very bottom decile and the top three deciles lost (all in relative terms).

Figure 1 illustrates the recent upsurge in globalization as reflected in the openness variable (ratio of trade to GDP in current dollar terms) and the increased importance of direct foreign investments as a percentage of recipient countries' GDP. There is a sustained increase in the (unweighted) share of openness from around 70 percent in the mid-1980s to more than 90 percent at the turn of the century. The dollar-weighted share of trade in world GDP (not shown in the figure) increased from 38 percent to 44 percent. The higher unweighted ratio of trade to GDP reflects the fact that trade shares are greater for smaller (and poorer) countries. Even more dramatic was the increase in unweighted foreign direct investments, from less than 1 percent of GDP in the late 1980s to 4 percent in 2000 .

Of less interest are the other control variables, financial depth and democracy. Financial depth is measured simply as the ratio of M2 to GDP. Democracy is measured by the democracy variable from the PolityIV database and takes a value from 0 (absence of democracy) to 10 (best). ${ }^{12}$

11. Each country is one observation regardless of its population size.

12. The database was created by Monthy Marshall, Keith Jeggers, and Ted Gurr. The data are available online at www.cidcm.umd.edu/inscr/polity. Democracy is defined as "general openness of political institutions." Financial depth is measured using M2 (the variable 35L..ZF, money plus quasimoney from International Financial Statistics) and nominal GDP. 
Table 2. Mean-Normalized Average Incomes by Decile (across countries, not weighted for population)

\begin{tabular}{|c|c|c|c|c|c|c|}
\hline \multirow[b]{2}{*}{ Decile } & \multicolumn{3}{|c|}{ All Countries } & \multicolumn{3}{|c|}{$\begin{array}{c}\text { Balanced Panel } \\
\text { (common sample countries) }\end{array}$} \\
\hline & 1988 & 1993 & 1998 & 1988 & 1993 & 1998 \\
\hline First & 0.307 & 0.235 & 0.233 & 0.303 & 0.244 & 0.233 \\
\hline Second & 0.441 & 0.375 & 0.380 & 0.437 & 0.391 & 0.387 \\
\hline Third & 0.539 & 0.476 & 0.482 & 0.535 & 0.495 & 0.491 \\
\hline Fourth & 0.635 & 0.571 & 0.581 & 0.631 & 0.593 & 0.590 \\
\hline Fifth & 0.736 & 0.677 & 0.686 & 0.733 & 0.701 & 0.697 \\
\hline Sixth & 0.855 & 0.804 & 0.810 & 0.853 & 0.831 & 0.821 \\
\hline Seventh & 1.000 & 0.959 & 0.962 & 1.000 & 0.984 & 0.972 \\
\hline Eighth & 1.201 & 1.182 & 1.181 & 1.202 & 1.207 & 1.188 \\
\hline Ninth & 1.541 & 1.566 & 1.552 & 1.548 & 1.580 & 1.553 \\
\hline Tenth & 2.745 & 3.156 & 3.138 & 2.757 & 2.973 & 3.068 \\
\hline $\begin{array}{l}\text { Number } \\
\text { of countries }\end{array}$ & 95 & 113 & 113 & 82 & 82 & 82 \\
\hline Decile ratio ${ }^{a}$ & 8.9 & 13.4 & 13.5 & 9.1 & 12.2 & 13.2 \\
\hline
\end{tabular}

Note: Deciles are formed based on per capita income or expenditures obtained from household surveys.

${ }^{\text {a }}$ The ratio of the average income of the tenth decile to the first decile.

Source: Author's computations based on household survey data from the WYD database.

\section{Estimation of the Regressions}

Ten-level regressions are estimated, starting with the parsimonious formulation and moving to an extended formulation that includes real rate of interest and government expenditures as a share of GDP. ${ }^{13}$ Two types of estimation are performed: simultaneous decile estimation and instrumental variable GMM estimation, which instruments openness and government expenditure as a share of GDP by their lagged values and the country's population. The results of the different regressions are quite similar, so only the GMM estimates of the extended formulation are discussed here. ${ }^{14}$

The regression is an unbalanced panel run across 138 decile shares in 1988, 1993, and 1998 (table 3). ${ }^{15}$ The Hansen $J$ statistic (test of overidentifying

13. The nominal interest rate is the deposit rate on 12-month deposits as reported in the International Monetary Fund's (IMF) International Financial Statistics (various issues; the variable is 60L ... ZF). The real rate is obtained by deflating the nominal rate by the 12-month consumer price index (also as reported in International Financial Statistics). Government expenditures are the sum of central (consolidated accounts), local, and state or provincial government expenditures. The data are from the IMF's Government Financial Statistics.

14. The full results are available online at www.worldbank.org/research/inequality.

15. There are 321 total surveys. Some drop out because they lack other right-side variables. The dropout rate is much lower for the parsimonious formulation, which is run across 201 decile shares. The fact that key results are virtually identical for both samples is reassuring. 
Figure 1. Average Annual Trade to gDP Ratio (left scale) and Direct Foreign Investment to GDP Ratio (right scale) for a Large Sample of Countries (percent; unweighted, calculated in current dollars)

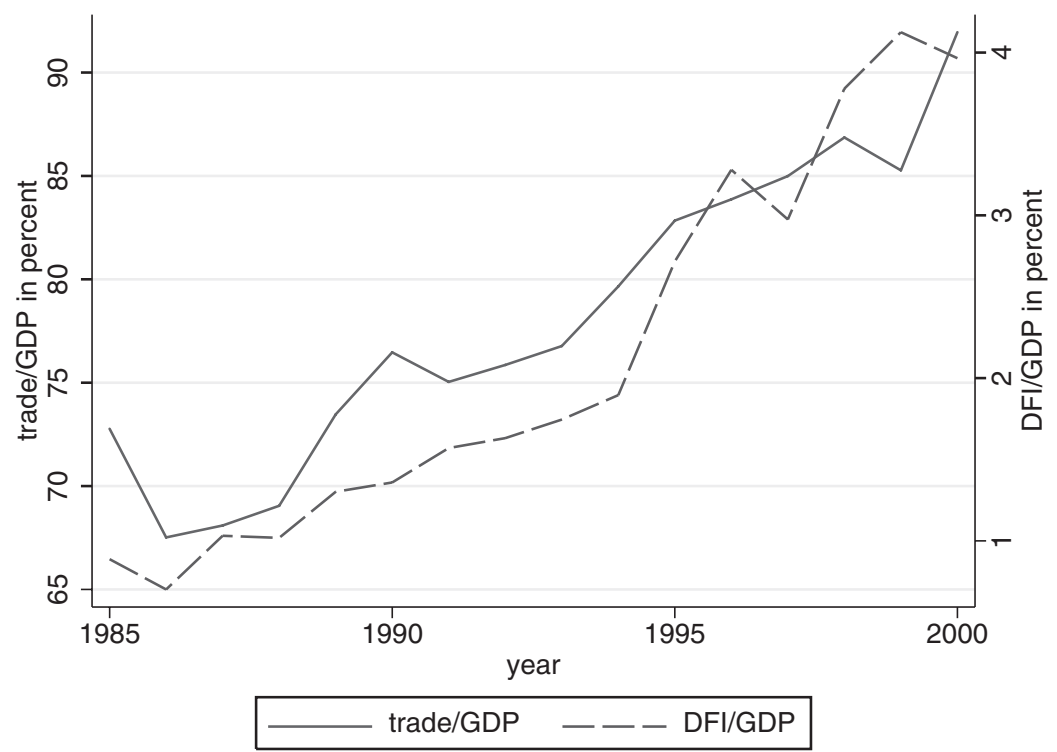

Note: The data on trade shares include nearly all countries in the world (the number ranges from 125 to 150). The data on foreign investment inflows include about 80 countries. Each country/year is one observation.

Source: For trade to GDP ratio, author's calculation based on World Bank data (World Development Indicators and Statistical Information Management and Analysis database); For direct foreign investment to GDP ratio, author's calculations based on UNCTAD $(1996,1997,2000)$.

restrictions) is insignificant throughout, indicating that instruments are valid. ${ }^{16}$ The F-test of excluded instruments (not reported in the table) is highly significant (value greater than 1,200), again implying that the instruments are appropriate. The results are as follows. Increased openness reduces the income shares of the bottom six deciles. The negative effect of openness is smaller in richer countries, for which the interaction term between openness and mean income is positive. Openness would therefore seem to have a particularly negative impact on poor and middle-income groups in poor countries-directly opposite to what would be expected from the standard Heckscher-Ohlin-Samuelson framework. Only when income level (calculated from household surveys) reaches about PPP\$7,500 (about

16. Hansen's $J$ statistic is consistent in the presence of heteroscedasticity, whereas its alternative, Sargan's statistic, is not. 
Table 3. Explaining Mean-Normalized Decile Incomes for 1988, 1993, and 1998 (GMm/instrumental variable estimation)

\begin{tabular}{|c|c|c|c|c|c|c|c|c|c|c|}
\hline Variable & $\begin{array}{l}\text { First } \\
\text { Decile }\end{array}$ & $\begin{array}{l}\text { Second } \\
\text { Decile }\end{array}$ & $\begin{array}{l}\text { Third } \\
\text { Decile }\end{array}$ & $\begin{array}{l}\text { Fourth } \\
\text { Decile }\end{array}$ & $\begin{array}{l}\text { Fifth } \\
\text { Decile }\end{array}$ & $\begin{array}{l}\text { Sixth } \\
\text { Decile }\end{array}$ & $\begin{array}{l}\text { Seventh } \\
\text { Decile }\end{array}$ & $\begin{array}{l}\text { Eighth } \\
\text { Decile }\end{array}$ & $\begin{array}{l}\text { Ninth } \\
\text { Decile }\end{array}$ & $\begin{array}{l}\text { Tenth } \\
\text { Decile }\end{array}$ \\
\hline Openness5 & $\begin{array}{l}-0.102 * * \\
(0.029)\end{array}$ & $\begin{array}{l}-0.137 * * \\
(0.005)\end{array}$ & $\begin{array}{l}-0.138 * * \\
(0.005)\end{array}$ & $\begin{array}{l}-0.135 * * \\
(0.005)\end{array}$ & $\begin{array}{l}-0.118 * * \\
(0.007)\end{array}$ & $\begin{array}{l}-0.094 * * \\
(0.019)\end{array}$ & $\begin{array}{r}-0.065 \\
(0.055)\end{array}$ & $\begin{array}{r}-0.001 \\
(0.978)\end{array}$ & $\begin{array}{c}0.090 \\
(0.086)\end{array}$ & $\begin{array}{l}0.695 * * \\
(0.013)\end{array}$ \\
\hline Expgdp5 & $\begin{array}{l}0.244 * * \\
(0)\end{array}$ & $\begin{array}{l}0.304 * * \\
(0)\end{array}$ & $\begin{array}{l}0.297 * * \\
(0)\end{array}$ & $\begin{array}{l}0.286 * * \\
(0)\end{array}$ & $\begin{array}{l}0.263 * * \\
(0)\end{array}$ & $\begin{array}{l}0.213 * * \\
(0)\end{array}$ & $\begin{array}{l}0.150 * * \\
(0)\end{array}$ & $\begin{array}{c}0.043 \\
(0.148)\end{array}$ & $\begin{array}{c}-0.147 * * \\
(0.014)\end{array}$ & $\begin{array}{c}-1.637 * * \\
(0)\end{array}$ \\
\hline $\begin{array}{l}\text { Mean income } \\
\quad \text { (in PpP\$000) }\end{array}$ & $\begin{array}{r}-0.003 \\
(0.587)\end{array}$ & $\begin{array}{c}-0.001 \\
(0.841)\end{array}$ & $\begin{array}{c}-0.001 \\
(0.861)\end{array}$ & $\begin{array}{r}-0.001 \\
(0.861)\end{array}$ & $\begin{array}{c}-0.0002 \\
(0.971)\end{array}$ & $\begin{array}{c}0.001 \\
(0.829)\end{array}$ & $\begin{array}{c}0.001 \\
(0.741)\end{array}$ & $\begin{array}{c}0.003 \\
(0.331)\end{array}$ & $\begin{array}{c}-0.0009 \\
(0.889)\end{array}$ & $\begin{array}{c}0.001 \\
(0.969)\end{array}$ \\
\hline$M 2 g d p 5$ & $\begin{array}{l}0.097 * * \\
(0.008)\end{array}$ & $\begin{array}{l}0.128 * * \\
(0.001)\end{array}$ & $\begin{array}{l}0.116 * * \\
(0.003)\end{array}$ & $\begin{array}{l}0.102^{* *} \\
(0.006)\end{array}$ & $\begin{array}{l}0.089 * * \\
(0.01)\end{array}$ & $\begin{array}{l}0.081 * * \\
(0.008)\end{array}$ & $\begin{array}{l}0.068 * * \\
(0.012)\end{array}$ & $\begin{array}{c}0.048 \\
(0.056)\end{array}$ & $\begin{array}{c}0.001 \\
(0.976)\end{array}$ & $\begin{array}{c}-0.749 * * \\
(0.001)\end{array}$ \\
\hline DFI5 & $\begin{array}{c}0.003 \\
(0.596)\end{array}$ & $\begin{array}{c}0.001 \\
(0.833)\end{array}$ & $\begin{array}{r}-0.002 \\
(0.737)\end{array}$ & $\begin{array}{c}-0.003 \\
(0.622)\end{array}$ & $\begin{array}{r}-0.005 \\
(0.441)\end{array}$ & $\begin{array}{c}-0.007 \\
(0.265)\end{array}$ & $\begin{array}{c}-0.008 \\
(0.148)\end{array}$ & $\begin{array}{c}-0.008 \\
(0.08)\end{array}$ & $\begin{array}{r}-0.007 \\
(0.239)\end{array}$ & $\begin{array}{c}0.037 \\
(0.335)\end{array}$ \\
\hline $\begin{array}{l}\text { DFI5 * } \\
\text { mean income }\end{array}$ & $\begin{array}{l}-0.003 * * \\
(0.034)\end{array}$ & $\begin{array}{l}-0.003 * * \\
(0.032)\end{array}$ & $\begin{array}{r}-0.002 \\
(0.113)\end{array}$ & $\begin{array}{c}-0.002 \\
(0.11)\end{array}$ & $\begin{array}{r}-0.002 \\
(0.168)\end{array}$ & $\begin{array}{r}-0.001 \\
(0.365)\end{array}$ & $\begin{array}{c}-0.0005 \\
(0.737)\end{array}$ & $\begin{array}{c}0.0005 \\
(0.734)\end{array}$ & $\begin{array}{l}0.003 * * \\
(0.031)\end{array}$ & $\begin{array}{c}0.011 \\
(0.239)\end{array}$ \\
\hline Democracy5 & $\begin{array}{r}-0.002 \\
(0.646)\end{array}$ & $\begin{array}{c}0.004 \\
(0.288)\end{array}$ & $\begin{array}{c}0.006 \\
(0.102)\end{array}$ & $\begin{array}{l}0.007 * * \\
(0.037)\end{array}$ & $\begin{array}{l}0.008 * * \\
(0.015)\end{array}$ & $\begin{array}{l}0.008 * * \\
(0.007)\end{array}$ & $\begin{array}{l}0.007 * * \\
(0.006)\end{array}$ & $\begin{array}{c}0.005 \\
(0.083)\end{array}$ & $\begin{array}{c}-0.0005 \\
(0.901)\end{array}$ & $\begin{array}{r}-0.043 \\
(0.056)\end{array}$ \\
\hline Rint5 & $\begin{array}{c}-0.001 * * \\
(0.003)\end{array}$ & $\begin{array}{c}-0.002 * * \\
(0)\end{array}$ & $\begin{array}{c}-0.002 * * \\
(0)\end{array}$ & $\begin{array}{c}-0.002 * * \\
(0)\end{array}$ & $\begin{array}{c}-0.002^{* * *} \\
(0)\end{array}$ & $\begin{array}{c}-0.002^{* * *} \\
(0)\end{array}$ & $\begin{array}{c}-0.001 * * \\
(0.002)\end{array}$ & $\begin{array}{c}-0.001 * * \\
(0.017)\end{array}$ & $\begin{array}{l}0.002 * * \\
(0.013)\end{array}$ & $\begin{array}{c}0.010 * * \\
(0)\end{array}$ \\
\hline Constant & $\begin{array}{c}0.164 * * \\
(0)\end{array}$ & $\begin{array}{l}0.237 * * \\
(0)\end{array}$ & $\begin{array}{l}0.335 * \\
(0)\end{array}$ & $\begin{array}{l}0.432 * * \\
(0)\end{array}$ & $\begin{array}{l}0.540 * * \\
(0)\end{array}$ & $\begin{array}{l}0.676^{* *} \\
(0)\end{array}$ & $\begin{array}{l}0.858 * * \\
(0)\end{array}$ & $\begin{array}{l}1.121^{* * *} \\
(0)\end{array}$ & $\begin{array}{c}1.626^{* * *} \\
(0)\end{array}$ & $\begin{array}{c}4.031^{* *} \\
(0)\end{array}$ \\
\hline Hansen $J$ & $\begin{array}{c}0.317 \\
(0.573)\end{array}$ & $\begin{array}{c}0.031 \\
(0.860)\end{array}$ & $\begin{array}{c}0.342 \\
(0.558)\end{array}$ & $\begin{array}{c}0.671 \\
(0.413)\end{array}$ & $\begin{array}{c}0.891 \\
(0.345)\end{array}$ & $\begin{array}{c}0.955 \\
(0.328)\end{array}$ & $\begin{array}{c}1.070 \\
(0.301)\end{array}$ & $\begin{array}{c}0.946 \\
(0.3306)\end{array}$ & $\begin{array}{c}1.810 \\
(0.178)\end{array}$ & $\begin{array}{c}0.978 \\
(0.323)\end{array}$ \\
\hline $\begin{array}{l}\text { Number of } \\
\text { observations }\end{array}$ & 135 & 138 & 138 & 138 & 138 & 138 & 138 & 138 & 138 & 138 \\
\hline Centered $R^{2}$ & 0.3326 & 0.5015 & 0.5248 & 0.5431 & 0.5569 & 0.5491 & 0.5011 & 0.2537 & 0.2491 & 0.5234 \\
\hline
\end{tabular}

$*$ Significant at the 1 or 5 percent level.

Note: The dependent variable is the decile mean income/overall mean income. Numbers in parentheses are $p$-values. Openness and government expenditure as share of GDP are instrumented. GMM calculations are performed using the ivreg2.ado routine developed by Baum and others (2002). A suffix of 5 indicates a five-year average. Government expenditures, openness, and M2 are expressed as a share of GDP (such as 0.3 not 30 percent); DFI/GDP is expressed as a percentage. Real rate of interest is expressed as an annual percentage. Mean income is expressed in 1995 PpP dollars. Regressions are run with robust standard errors.

Source: Author's computations based on household survey data from the WYD database. 
the level of Spain and Israel) does openness become a good thing for poor and middle-income groups by raising their share in total income. ${ }^{17}$

How large is the openness effect? Consider a poor country with a mean income of PPP\$2,000 per capita and whose second decile's share of income is about 4 percent (an average value in the sample). The second decile's mean per capita income is therefore PPP $\$ 800$. An increase from 0.7 to 0.9 in the trade to GDP ratio (an average change between 1985 and 2000) reduces the decile's share of income to about 3.8 percent and its mean per capita income to PPP\$760 in absolute terms (of course, absent any other effect, including a change in total income). ${ }^{18}$

Direct foreign investment is not statistically significant, whether alone or interacted with income. ${ }^{19}$ Neither is real mean income alone. Financial depth, as expected, increases the income share of the poor and middle class and reduces the share of the top decile.

Democracy positively affects the income shares of the middle deciles. An interesting result, this suggests that earlier work failed to detect the effect of democracy on inequality (Bollen and Jackman 1985; Gradstein and others 2001) because democracy affects primarily the income shares of the middle groups while leaving the shares of the top and the bottom deciles unchanged. ${ }^{20}$ As a consequence, synthetic inequality measures, such as the Gini coefficient, may not show much change.

The real interest rate is shown to be statistically significant throughout and strongly antipoor: It reduces the share of the bottom eight deciles and raises that of the top two. How strong is this effect? The income share of the top decile is about 30 percent. Each percentage point increase in the real rate of interest raises that share by about 0.1 percentage point. In other words, the real income of the rich (assuming total income remains fixed) goes up by one-third of 1 percent.

Government expenditure plays a role directly opposite that of high real interest rates. A 10 percentage point increase in the ratio of government expenditure to GDP raises the bottom decile's share of the pie by 0.24 percentage point-about onetenth of what the bottom decile received on average (see table 2 ).

Next, the sensitivity of these results to changes in specification is tested. When regional dummy variables (with Western Europe-North America-Oceania, or WENAO, as the reference category) and the five-year average rate of inflation are

17. The turning point is somewhat lower using the formulation with financial depth and democracy only. It is present in all cases, however. One should attach much less confidence to the exact income level at which the turn occurs than to its existence. Note that Barro (2000, p. 28) finds the turning point to be around GDP per capita of PPP\$13,000 (in 1985 prices).

18. This is obtained as follows. At PPP $\$ 2,000$, the sensitivity of the decile ratio variable is $-0.137+(0.02 * 2)=-0.01$, which means that with a unitary increase in openness, the decile ratio will go down by 0.1 (see table 3 ). If openness now increases from 0.7 to 0.9 , the effect will be $(0.9-0.7)$ * $0.1=0.02$ or 0.2 percentage point. So, the effect of a 20 percentage point increase in the trade share will be a decline of 0.2 percentage point in the second decile's income share.

19. Except for the bottom two deciles for the interaction term.

20. For an exception see Tavares and Wacziarg (2001). 
added, the general quality of the results improves and $R^{2}$ rises to a rather high average value of 0.7 (table 4 ). The role of openness becomes sharper: It reduces the share of the bottom seven deciles and raises that of the top two. Its level of significance also becomes very high. The interaction term between openness and income is equally statistically significant almost throughout. The turning point now occurs around Ppp $\$ 8,000$. Government expenditures are still propoor, and the real rate of interest is prorich and a significantly strong predictor of income shares across the entire distribution. As expected from the literature, inflation is strongly significant and negatively affects the income shares of the poor and the middle class. The regional dummy variables for Latin America, and Eastern Europe and the former Soviet Union are significant almost throughout, the first being antipoor and the second propoor (compared with the omitted WENAO dummy variable). Both Africa and Asia show lower shares for the middle deciles.

Finally, the sensitivity of the results to different definitions of openness is examined and compared with the results of Dollar and Kraay (2001, 2002). Several alternative definitions of openness are used here: the ratio of trade to GDP in constant U.S. dollars converted at market exchange rates (the volume of trade variable kopen in Penn World Table 6.1) and the ratio of exports to GDP in current prices. Both formulations yield the same results as the preferred measure does (trade to GDP in current dollars). ${ }^{21}$

Perhaps more interesting is to explore the difference between these results and those reported by Dollar and Kraay (2002). Their much-quoted article reaches two important conclusions: first, that the growth rate of the bottom quintile displays on average a unitary elasticity (meaning that the poor's percentage increase in income is the same as the mean increase), and second, that openness does not significantly affect the income share of the bottom quintile. This second finding differs from the results found here. The difference may be due to a difference in the sample (unlikely, however, because the samples include largely the same countries), the period covered (Dollar and Kraay's data go back to the 1970s), or the inequality measure used (that used for this study is better because the deciles are almost all calculated directly from individual household surveys, whereas Dollar and Kraay's quintile data come from a heterogeneous collection of sources, with many of them being extrapolations).

The most important difference, however, is in the definition of the openness variable. This study defines openness as the trade to GDP ratio, both expressed in nominal dollar terms. Dollar and Kraay define openness rather unusually as the ratio between trade in 1985 dollars and GDP in 1985 international dollars. It is a consistent definition, because both the numerator and the denominator are in international dollars (trade is by definition conducted at international prices), but it is a different indicator from (say) the volume of trade as given in Penn World Table 6.1. There, trade is also in the numerator (in the same 1985 prices), but GDP is

21. For reasons of space, the results are not reported here, but they are available from the author. 
Table 4. Explaining Mean-Normalized Decile Incomes for 1988, 1993, 1998: Adding Regional Dummy Variables and Inflation (GMM/instrumental variable estimation)

\begin{tabular}{|c|c|c|c|c|c|c|c|c|c|c|}
\hline Variable & $\begin{array}{l}\text { First } \\
\text { Decile }\end{array}$ & $\begin{array}{l}\text { Second } \\
\text { Decile }\end{array}$ & $\begin{array}{l}\text { Third } \\
\text { Decile }\end{array}$ & $\begin{array}{l}\text { Fourth } \\
\text { Decile }\end{array}$ & $\begin{array}{l}\text { Fifth } \\
\text { Decile }\end{array}$ & $\begin{array}{l}\text { Sixth } \\
\text { Decile }\end{array}$ & $\begin{array}{l}\text { Seventh } \\
\text { Decile }\end{array}$ & $\begin{array}{l}\text { Eighth } \\
\text { Decile }\end{array}$ & $\begin{array}{l}\text { Ninth } \\
\text { Decile }\end{array}$ & $\begin{array}{l}\text { Tenth } \\
\text { Decile }\end{array}$ \\
\hline Openness5 & $\begin{array}{c}-0.149 * * \\
(0)\end{array}$ & $\begin{array}{l}-0.199 * * \\
(0)\end{array}$ & $\begin{array}{c}-0.200 * * \\
(0)\end{array}$ & $\begin{array}{c}-0.199 * * \\
(0)\end{array}$ & $\begin{array}{c}-0.176 * * \\
(0)\end{array}$ & $\begin{array}{c}-0.143 * * \\
(0)\end{array}$ & $\begin{array}{l}-0.096 * * \\
(0.002)\end{array}$ & $\begin{array}{r}-0.012 \\
(0.699)\end{array}$ & $\begin{array}{l}0.171 * * \\
(0.001)\end{array}$ & $\begin{array}{l}1.032 * * \\
(0)\end{array}$ \\
\hline Expgdp5 & $\begin{array}{l}0.146 * * \\
(0.013)\end{array}$ & $\begin{array}{l}0.187 * * \\
(0.001)\end{array}$ & $\begin{array}{l}0.139 * * \\
(0.008)\end{array}$ & $\begin{array}{l}0.111 * * \\
(0.028)\end{array}$ & $\begin{array}{l}0.079 \\
(0.1)\end{array}$ & $\begin{array}{c}0.027 \\
(0.566)\end{array}$ & $\begin{array}{r}-0.019 \\
(0.668)\end{array}$ & $\begin{array}{c}-0.053 \\
(0.195)\end{array}$ & $\begin{array}{c}-0.064 \\
(0.255)\end{array}$ & $\begin{array}{c}-0.481 \\
(0.148)\end{array}$ \\
\hline $\begin{array}{l}\text { Mean income } \\
\text { (in PPP\$000) }\end{array}$ & $\begin{array}{l}-0.010 * * \\
(0.047)\end{array}$ & $\begin{array}{l}-0.012 * * \\
(0.018)\end{array}$ & $\begin{array}{l}-0.014^{* *} \\
(0.004)\end{array}$ & $\begin{array}{l}-0.015^{* *} \\
(0.001)\end{array}$ & $\begin{array}{c}-0.014 * * \\
(0)\end{array}$ & $\begin{array}{l}-0.012 * * \\
(0.001)\end{array}$ & $\begin{array}{l}-0.010 * * \\
(0.001)\end{array}$ & $\begin{array}{c}-0.004 \\
(0.25)\end{array}$ & $\begin{array}{l}0.012 * * \\
(0.036)\end{array}$ & $\begin{array}{l}0.078 * * \\
(0.002)\end{array}$ \\
\hline $\begin{array}{l}\text { Openness } 5 * \\
\text { mean income }\end{array}$ & $\begin{array}{l}0.019 * * \\
(0.001)\end{array}$ & $\begin{array}{l}0.026^{* *} \\
(0)\end{array}$ & $\begin{array}{l}0.025 * * \\
(0)\end{array}$ & $\begin{array}{l}0.024 * * \\
(0)\end{array}$ & $\begin{array}{l}0.022 * * \\
(0)\end{array}$ & $\begin{array}{l}0.017 * * \\
(0)\end{array}$ & $\begin{array}{l}0.011 * * \\
(0.005)\end{array}$ & $\begin{array}{c}-0.0005 \\
(0.918)\end{array}$ & $\begin{array}{c}-0.024 * * \\
(0.005)\end{array}$ & $\begin{array}{c}-0.123 * * \\
(0)\end{array}$ \\
\hline$M 2 g d p 5$ & $\begin{array}{c}0.006 \\
(0.854)\end{array}$ & $\begin{array}{c}0.007 \\
(0.821)\end{array}$ & $\begin{array}{c}0.018 \\
(0.546)\end{array}$ & $\begin{array}{c}0.026 \\
(0.394)\end{array}$ & $\begin{array}{c}0.030 \\
(0.29)\end{array}$ & $\begin{array}{c}0.037 \\
(0.179)\end{array}$ & $\begin{array}{c}0.040 \\
(0.116)\end{array}$ & $\begin{array}{c}0.041 \\
(0.14)\end{array}$ & $\begin{array}{c}0.054 \\
(0.274)\end{array}$ & $\begin{array}{c}-0.343 \\
(0.081)\end{array}$ \\
\hline DFI5 & $\begin{array}{l}0.0006 \\
(0.88)\end{array}$ & $\begin{array}{c}-0.003 \\
(0.468)\end{array}$ & $\begin{array}{c}-0.005 \\
(0.161)\end{array}$ & $\begin{array}{c}-0.004 \\
(0.237)\end{array}$ & $\begin{array}{r}-0.005 \\
(0.212)\end{array}$ & $\begin{array}{c}-0.006 \\
(0.135)\end{array}$ & $\begin{array}{r}-0.007 \\
(0.106)\end{array}$ & $\begin{array}{r}-0.008 \\
(0.095)\end{array}$ & $\begin{array}{c}-0.009 \\
(0.129)\end{array}$ & $\begin{array}{c}0.038 \\
(0.129)\end{array}$ \\
\hline $\begin{array}{l}\text { DFI5* } \\
\text { mean income }\end{array}$ & $\begin{array}{l}-0.003 * \% \\
(0.038)\end{array}$ & $\begin{array}{l}-0.002 * * \\
(0.04)\end{array}$ & $\begin{array}{c}-0.002 \\
(0.051)\end{array}$ & $\begin{array}{l}-0.002 * * \\
(0.018)\end{array}$ & $\begin{array}{l}-0.002 * * \\
(0.02)\end{array}$ & $\begin{array}{r}-0.001 \\
(0.114)\end{array}$ & $\begin{array}{c}-0.0005 \\
(0.569)\end{array}$ & $\begin{array}{c}0.0005 \\
(0.619)\end{array}$ & $\begin{array}{l}0.003 * * \\
(0.031)\end{array}$ & $\begin{array}{c}0.011 \\
(0.058)\end{array}$ \\
\hline Democracy 5 & $\begin{array}{c}0.003 \\
(0.416)\end{array}$ & $\begin{array}{l}0.008 * * \\
(0.001)\end{array}$ & $\begin{array}{c}0.009 * * \\
(0)\end{array}$ & $\begin{array}{l}0.009 * * \\
(0)\end{array}$ & $\begin{array}{l}0.009 * * \\
(0.001)\end{array}$ & $\begin{array}{l}0.009 * * \\
(0.001)\end{array}$ & $\begin{array}{l}0.008^{* *} \\
(0.004)\end{array}$ & $\begin{array}{c}0.006 \\
(0.052)\end{array}$ & $\begin{array}{c}0.001 \\
(0.897)\end{array}$ & $\begin{array}{c}-0.056^{* *} \\
(0.003)\end{array}$ \\
\hline Rint5 & $\begin{array}{c}-0.001 * * \\
(0.018)\end{array}$ & $\begin{array}{l}-0.001 * * \\
(0.004)\end{array}$ & $\begin{array}{l}-0.0009 * * \\
(0.004)\end{array}$ & $\begin{array}{l}-0.001 * * \\
(0.002)\end{array}$ & $\begin{array}{c}-0.001 * \% \\
(0.001)\end{array}$ & $\begin{array}{c}-0.001 * * \\
(0.001)\end{array}$ & $\begin{array}{c}-0.0009 * * \\
(0.009)\end{array}$ & $\begin{array}{c}-0.0007 \\
(0.05)\end{array}$ & $\begin{array}{l}0.002 * * \\
(0)\end{array}$ & $\begin{array}{l}0.005 * * \\
(0.005)\end{array}$ \\
\hline Linf5 & $\begin{array}{c}-0.022 * * \\
(0.003)\end{array}$ & $\begin{array}{c}-0.032 * * \\
(0)\end{array}$ & $\begin{array}{c}-0.032 * * \\
(0)\end{array}$ & $\begin{array}{l}-0.033 * * \\
(0)\end{array}$ & $\begin{array}{c}-0.030 * * \\
(0)\end{array}$ & $\begin{array}{c}-0.026^{* *} \\
(0)\end{array}$ & $\begin{array}{l}-0.017 * * \\
(0.005)\end{array}$ & $\begin{array}{c}-0.008 \\
(0.228)\end{array}$ & $\begin{array}{l}0.045 * * \\
(0)\end{array}$ & $\begin{array}{c}0.159 * * \\
(0)\end{array}$ \\
\hline Africa & $\begin{array}{c}-0.010 \\
(0.801)\end{array}$ & $\begin{array}{c}-0.028 \\
(0.464)\end{array}$ & $\begin{array}{c}-0.062 \\
(0.082)\end{array}$ & $\begin{array}{c}-0.083 * * \\
(0.018)\end{array}$ & $\begin{array}{c}-0.096 * \% \\
(0.005)\end{array}$ & $\begin{array}{c}-0.099 * * \\
(0.004)\end{array}$ & $\begin{array}{c}-0.092 * * \\
(0.008)\end{array}$ & $\begin{array}{c}-0.041 \\
(0.308)\end{array}$ & $\begin{array}{c}0.083 \\
(0.134)\end{array}$ & $\begin{array}{c}0.475 \\
(0.068)\end{array}$ \\
\hline Asia & $\begin{array}{c}0.067 \\
(0.091)\end{array}$ & $\begin{array}{c}0.026 \\
(0.521)\end{array}$ & $\begin{array}{r}-0.016 \\
(0.633)\end{array}$ & $\begin{array}{c}-0.041 \\
(0.208)\end{array}$ & $\begin{array}{c}-0.063 * * \\
(0.034)\end{array}$ & $\begin{array}{c}-0.083 * * \\
(0.003)\end{array}$ & $\begin{array}{c}-0.098 * * \\
(0)\end{array}$ & $\begin{array}{c}-0.086^{* *} \\
(0)\end{array}$ & $\begin{array}{c}-0.011 \\
(0.761)\end{array}$ & $\begin{array}{c}0.301 \\
(0.144)\end{array}$ \\
\hline
\end{tabular}


TABLE 4. Continued

\begin{tabular}{|c|c|c|c|c|c|c|c|c|c|c|}
\hline Variable & $\begin{array}{c}\text { First } \\
\text { Decile }\end{array}$ & $\begin{array}{l}\text { Second } \\
\text { Decile }\end{array}$ & $\begin{array}{l}\text { Third } \\
\text { Decile }\end{array}$ & $\begin{array}{l}\text { Fourth } \\
\text { Decile }\end{array}$ & $\begin{array}{l}\text { Fifth } \\
\text { Decile }\end{array}$ & $\begin{array}{l}\text { Sixth } \\
\text { Decile }\end{array}$ & $\begin{array}{l}\text { Seventh } \\
\text { Decile }\end{array}$ & $\begin{array}{l}\text { Eighth } \\
\text { Decile }\end{array}$ & $\begin{array}{l}\text { Ninth } \\
\text { Decile }\end{array}$ & $\begin{array}{l}\text { Tenth } \\
\text { Decile }\end{array}$ \\
\hline Latin America & $\begin{array}{c}-0.082 * * \\
(0.011)\end{array}$ & $\begin{array}{c}-0.102 * * \\
(0.001)\end{array}$ & $\begin{array}{c}-0.124 * * \\
(0)\end{array}$ & $\begin{array}{c}-0.135 * * \\
(0)\end{array}$ & $\begin{array}{c}-0.140 * * \\
(0)\end{array}$ & $\begin{array}{c}-0.141^{* *} \\
(0)\end{array}$ & $\begin{array}{c}-0.130 * * \\
(0)\end{array}$ & $\begin{array}{c}-0.077 * * \\
(0.001)\end{array}$ & $\begin{array}{c}0.063 \\
(0.069)\end{array}$ & $\begin{array}{c}0.886 * * \\
(0)\end{array}$ \\
\hline $\begin{array}{l}\text { East Europe and } \\
\text { former Soviet Union }\end{array}$ & $\begin{array}{l}0.125 * * \\
(0.001)\end{array}$ & $\begin{array}{l}0.140 * * \\
(0)\end{array}$ & $\begin{array}{l}0.132 * * \\
(0)\end{array}$ & $\begin{array}{l}0.116 * * \\
(0)\end{array}$ & $\begin{array}{l}0.091 * * \\
(0)\end{array}$ & $\begin{array}{l}0.063 * * \\
(0.003)\end{array}$ & $\begin{array}{c}0.024 \\
(0.224)\end{array}$ & $\begin{array}{r}-0.024 \\
(0.289)\end{array}$ & $\begin{array}{l}-0.117^{* *} \\
(0.002)\end{array}$ & $\begin{array}{c}-0.572^{* *} \\
(0)\end{array}$ \\
\hline Constant & $\begin{array}{l}0.323^{* *} \\
(0)\end{array}$ & $\begin{array}{l}0.480 * * \\
(0)\end{array}$ & $\begin{array}{l}0.618^{* *} \\
(0)\end{array}$ & $\begin{array}{l}0.739 * * \\
(0)\end{array}$ & $\begin{array}{l}0.846 * * \\
(0)\end{array}$ & $\begin{array}{l}0.966^{* *} \\
(0)\end{array}$ & $\begin{array}{l}1.098 * * \\
(0)\end{array}$ & $\begin{array}{l}1.244 * * \\
(0)\end{array}$ & $\begin{array}{l}1.336 * * \\
(0)\end{array}$ & $\begin{array}{l}2.298^{* * *} \\
(0)\end{array}$ \\
\hline Hansen $J$ & $\begin{array}{c}3.647 \\
(0.058)\end{array}$ & $\begin{array}{c}2.936 \\
(0.086)\end{array}$ & $\begin{array}{c}0.903 \\
(0.342)\end{array}$ & $\begin{array}{c}0.044 \\
(0.833)\end{array}$ & $\begin{array}{c}0.104 \\
(0.746)\end{array}$ & $\begin{array}{c}0.432 \\
(0.511)\end{array}$ & $\begin{array}{c}1.020 \\
(0.312)\end{array}$ & $\begin{array}{l}1.569 \\
(0.2104)\end{array}$ & $\begin{array}{c}2.992 \\
(0.083)\end{array}$ & $\begin{array}{c}0.382 \\
(0.536)\end{array}$ \\
\hline $\begin{array}{l}\text { Number of } \\
\text { observations }\end{array}$ & 135 & 138 & 138 & 138 & 138 & 138 & 138 & 138 & 138 & 138 \\
\hline Centered $R^{2}$ & 0.619 & 0.735 & 0.756 & 0.768 & 0.768 & 0.746 & 0.670 & 0.3407 & 0.444 & 0.725 \\
\hline
\end{tabular}

$*$ Significant at the 1 or 5 percent level.

Note: The dependent variable is the decile mean income/overall mean income. Numbers in parentheses are $p$-values. Openness and government expenditure as share of GDP are instrumented. GMM calculations are performed using the ivreg2.ado routine developed by Baum and others (2002). A suffix of 5 indicates a five-year average. Government expenditures, openness, and M2 are expressed as a share of GDP (such as 0.3 not 30 percent); DFI/GDP is expressed as a percentage. Real rate of interest is expressed as an annual percentage. Mean income is expressed in 1995 pPp dollars. The omitted region is Western Europe, North America, and Oceania (Australia and New Zealand). Regressions are run with robust standard errors.

Source: Author's computations based on household survey data from the WYD database. 
calculated in exchange rate dollars of the same year. The difference is important because using PPP dollars to express the denominator significantly increases GDP for poor countries and thus reduces the importance of trade in their GDP.

When the previous regression is run with the Dollar and Kraay measure of openness, ${ }^{22}$ the results change in an important way (see table 5). Openness is no longer significant for any decile, nor is the interaction between openness and income. In other words, openness does not matter for income distribution. ${ }^{23}$

To see why there is a difference in the results obtained by these two measures of openness, consider how they behave when trade in poor countries expands. ${ }^{24}$ The effect on the Dollar and Kraay measure will be small because the bulk of these countries' GDP will still consist of nontradables that are valued at (high) international prices. But the effect on the trade to GDP ratio in both current and constant prices (at market exchange rates) may be large. Consider India and China. In nominal terms, the trade to GDP ratio in India increased from 16 percent in 1985 to 31 percent in 2000 and in China from 21 percent to 49 percent. In volumes (given by Penn World Table 6.1) the increase was from 19 percent of GDP to 25 percent for India and from 12 percent of GDP to 53 percent for China. In the ppp terms used by Dollar and Kraay, however, the trade ratio barely budged over the same period, going from 4 percent to 5 percent in India and from 3 percent to 12 percent in China. ${ }^{25}$

A stark illustration of the difference implied by the use of different measures is shown in figures 2 and 3, where the lowest line is always the Dollar and Kraay measure and the ratio of trade to GDP in current prices and in constant prices move almost in unison.

Now consider the situation in which income inequality rises simultaneously with increases in trade in both countries (as indeed it did). The Dollar and Kraay measure will fail to detect much of a relationship between openness and inequality because the measure is artificially sluggish. With the measure used here, however, an increase in openness will be associated with greater inequality.

22. The measure is calculated, following Dollar and Kraay, from Penn World Table 6.1 as (exports + imports) expressed in local currency and at 1996 constant prices divided by the 1996 exchange rate and then by the 1996 GDP per capita in international dollars (variable rgdpch from Penn World Table 6.1). Similar results are obtained using World Bank data, where trade in current U.S. dollars is divided by the U.S. Consumer Price Index (with 1995 as the base year) and then by the 1995 GDP per capita in international prices. The World Bank measure takes into account terms of trade effect.

23. The general quality of the regressions goes down although government expenditures as share of GDP, democracy, and real rate of interest behave about the same as in earlier.

24. In general, there would be no important difference between the two measures for the rich countries because their GDPs calculated at PPP or market exchange rates are similar. However, even there, the differences do appear for countries like Sweden or Germany whose price level is higher than that of the United States (numeraire in the case of ppp calculations). Here, the bias is in the opposite direction: The ratio of trade to GDP in PPP terms will be higher than ratio of trade to GDP in current terms.

25. Not even the direction of change is always the same. For example, between 1980 and 2000 Indonesia's openness increased using current values (from 49 percent to 82 percent of GDP) while declining using GDP in PPP terms (from 17 percent to 13 percent). 
TA B LE 5. Explaining Mean-Normalized Decile Incomes for 1988, 1993, 1998: Changing the Definition of Openness to the Dollar-Kraay Measure (GMm/instrumental variable estimation)

\begin{tabular}{|c|c|c|c|c|c|c|c|c|c|c|}
\hline Variable & $\begin{array}{c}\text { First } \\
\text { Decile }\end{array}$ & $\begin{array}{l}\text { Second } \\
\text { Decile }\end{array}$ & $\begin{array}{l}\text { Third } \\
\text { Decile }\end{array}$ & $\begin{array}{l}\text { Fourth } \\
\text { Decile }\end{array}$ & $\begin{array}{l}\text { Fifth } \\
\text { Decile }\end{array}$ & $\begin{array}{l}\text { Sixth } \\
\text { Decile }\end{array}$ & $\begin{array}{l}\text { Seventh } \\
\text { Decile }\end{array}$ & $\begin{array}{l}\text { Eighth } \\
\text { Decile }\end{array}$ & $\begin{array}{l}\text { Ninth } \\
\text { Decile }\end{array}$ & $\begin{array}{l}\text { Tenth } \\
\text { Decile }\end{array}$ \\
\hline Open_ppp5 & $\begin{array}{r}-0.098 \\
(0.365)\end{array}$ & $\begin{array}{r}-0.083 \\
(0.482)\end{array}$ & $\begin{array}{r}-0.058 \\
(0.612)\end{array}$ & $\begin{array}{r}-0.037 \\
(0.73)\end{array}$ & $\begin{array}{r}-0.012 \\
(0.906)\end{array}$ & $\begin{array}{c}0.021 \\
(0.828)\end{array}$ & $\begin{array}{c}0.053 \\
(0.543)\end{array}$ & $\begin{array}{c}0.109 \\
(0.099)\end{array}$ & $\begin{array}{c}0.087 \\
(0.395)\end{array}$ & $\begin{array}{c}0.012 \\
(0.986)\end{array}$ \\
\hline Expgdp5 & $\begin{array}{l}0.234 * * \\
(0.004)\end{array}$ & $\begin{array}{l}0.277^{* *} \\
(0)\end{array}$ & $\begin{array}{l}0.271 * * \\
(0)\end{array}$ & $\begin{array}{c}0.260 * * \\
(0)\end{array}$ & $\begin{array}{c}0.236 * * \\
(0)\end{array}$ & $\begin{array}{l}0.183 * * \\
(0.002)\end{array}$ & $\begin{array}{l}0.117 * * \\
(0.015)\end{array}$ & $\begin{array}{c}0.008 \\
(0.808)\end{array}$ & $\begin{array}{c}-0.148 * * \\
(0.037)\end{array}$ & $\begin{array}{c}-1.448 * * \\
(0.001)\end{array}$ \\
\hline $\begin{array}{l}\text { Mean income } \\
\quad \text { (in PPP\$000) }\end{array}$ & $\begin{array}{c}-0.0001 \\
(0.984)\end{array}$ & $\begin{array}{c}0.003 \\
(0.615)\end{array}$ & $\begin{array}{c}0.005 \\
(0.456)\end{array}$ & $\begin{array}{c}0.005 \\
(0.341)\end{array}$ & $\begin{array}{c}0.006 \\
(0.223)\end{array}$ & $\begin{array}{c}0.007 \\
(0.119)\end{array}$ & $\begin{array}{c}0.007 \\
(0.091)\end{array}$ & $\begin{array}{l}0.007 * * \\
(0.045)\end{array}$ & $\begin{array}{c}-0.002 \\
(0.72)\end{array}$ & $\begin{array}{r}-0.039 \\
(0.244)\end{array}$ \\
\hline $\begin{array}{l}\text { Open_ppp5 } \\
\text { mean income }\end{array}$ & $\begin{array}{c}0.0138 \\
(0.222)\end{array}$ & $\begin{array}{l}0.016 \\
(0.19)\end{array}$ & $\begin{array}{l}0.013 \\
(0.28)\end{array}$ & $\begin{array}{c}0.010 \\
(0.347)\end{array}$ & $\begin{array}{c}0.007 \\
(0.488)\end{array}$ & $\begin{array}{c}0.003 \\
(0.78)\end{array}$ & $\begin{array}{c}-0.002 \\
(0.82)\end{array}$ & $\begin{array}{r}-0.010 \\
(0.131)\end{array}$ & $\begin{array}{r}-0.016 \\
(0.133)\end{array}$ & $\begin{array}{r}-0.033 \\
(0.619)\end{array}$ \\
\hline$M 2 g d p 5$ & $\begin{array}{l}0.1003 * * \\
(0.004)\end{array}$ & $\begin{array}{l}0.115 * * \\
(0.004)\end{array}$ & $\begin{array}{l}0.091 * * \\
(0.022)\end{array}$ & $\begin{array}{c}0.075 \\
(0.051)\end{array}$ & $\begin{array}{c}0.063 \\
(0.073)\end{array}$ & $\begin{array}{c}0.057 \\
(0.072)\end{array}$ & $\begin{array}{c}0.046 \\
(0.092)\end{array}$ & $\begin{array}{c}0.034 \\
(0.159)\end{array}$ & $\begin{array}{c}0.005 \\
(0.899)\end{array}$ & $\begin{array}{r}-0.570 \\
(0.015)\end{array}$ \\
\hline DFI5 & $\begin{array}{c}0.001 \\
(0.854)\end{array}$ & $\begin{array}{r}-0.001 \\
(0.824)\end{array}$ & $\begin{array}{r}-0.005 \\
(0.367)\end{array}$ & $\begin{array}{r}-0.007 \\
(0.261)\end{array}$ & $\begin{array}{r}-0.008 \\
(0.166)\end{array}$ & $\begin{array}{r}-0.010 \\
(0.096)\end{array}$ & $\begin{array}{r}-0.010 \\
(0.059)\end{array}$ & $\begin{array}{r}-0.008 \\
(0.063)\end{array}$ & $\begin{array}{r}-0.004 \\
(0.469)\end{array}$ & $\begin{array}{c}0.056 \\
(0.118)\end{array}$ \\
\hline $\begin{array}{l}\text { DFI5 * } \\
\text { mean income }\end{array}$ & $\begin{array}{l}-0.003 * * \\
(0.028)\end{array}$ & $\begin{array}{l}-0.003 * * \\
(0.023)\end{array}$ & $\begin{array}{r}-0.002 \\
(0.105)\end{array}$ & $\begin{array}{r}-0.002 \\
(0.111)\end{array}$ & $\begin{array}{c}-0.002 \\
(0.166)\end{array}$ & $\begin{array}{r}-0.001 \\
(0.352)\end{array}$ & $\begin{array}{c}-0.0005 \\
(0.726)\end{array}$ & $\begin{array}{c}0.0003 \\
(0.821)\end{array}$ & $\begin{array}{c}0.002 \\
(0.103)\end{array}$ & $\begin{array}{c}0.010 \\
(0.201)\end{array}$ \\
\hline Democracy5 & $\begin{array}{c}-0.001 \\
(0.886)\end{array}$ & $\begin{array}{c}0.005 \\
(0.249)\end{array}$ & $\begin{array}{c}0.007 \\
(0.104)\end{array}$ & $\begin{array}{l}0.008 * * \\
(0.046)\end{array}$ & $\begin{array}{l}0.009 * * \\
(0.025)\end{array}$ & $\begin{array}{l}0.008 * * \\
(0.019)\end{array}$ & $\begin{array}{l}0.007 * * \\
(0.023)\end{array}$ & $\begin{array}{c}0.003 \\
(0.248)\end{array}$ & $\begin{array}{r}-0.002 \\
(0.622)\end{array}$ & $\begin{array}{c}-0.045 \\
(0.076)\end{array}$ \\
\hline Rint5 & $\begin{array}{c}-0.001 * * \\
(0.005)\end{array}$ & $\begin{array}{c}-0.002 * * \\
(0)\end{array}$ & $\begin{array}{c}-0.002 * * \\
(0)\end{array}$ & $\begin{array}{c}-0.002 * * \\
(0)\end{array}$ & $\begin{array}{c}-0.002 * * \\
(0.001)\end{array}$ & $\begin{array}{c}-0.002 * * \\
(0.001)\end{array}$ & $\begin{array}{c}-0.001 * * \\
(0.002)\end{array}$ & $\begin{array}{c}-0.001 * * \\
(0.013)\end{array}$ & $\begin{array}{l}0.002 * * \\
(0.017)\end{array}$ & $\begin{array}{c}0.009 * * \\
(0)\end{array}$ \\
\hline Constant & $\begin{array}{l}0.127 * * \\
(0)\end{array}$ & $\begin{array}{l}0.190 * * \\
(0)\end{array}$ & $\begin{array}{l}0.283 * * \\
(0)\end{array}$ & $\begin{array}{l}0.379 * * \\
(0)\end{array}$ & $\begin{array}{l}0.491 * * \\
(0)\end{array}$ & $\begin{array}{l}0.633 * * \\
(0)\end{array}$ & $\begin{array}{l}0.824 * * \\
(0)\end{array}$ & $\begin{array}{l}1.108 * * \\
(0)\end{array}$ & $\begin{array}{l}1.652 * * \\
(0)\end{array}$ & $\begin{array}{c}4.327 * * \\
(0)\end{array}$ \\
\hline Hansen $J$ & $\begin{array}{c}0.006 \\
(0.936)\end{array}$ & $\begin{array}{c}0.772 \\
(0.379)\end{array}$ & $\begin{array}{c}1.062 \\
(0.3026)\end{array}$ & $\begin{array}{c}1.285 \\
(0.2569)\end{array}$ & $\begin{array}{c}1.399 \\
(0.2369)\end{array}$ & $\begin{array}{c}1.412 \\
(0.2347)\end{array}$ & $\begin{array}{c}1.460 \\
(0.2269)\end{array}$ & $\begin{array}{c}1.213 \\
(0.2707)\end{array}$ & $\begin{array}{c}1.601 \\
(0.2057)\end{array}$ & $\begin{array}{c}1.450 \\
(0.2285)\end{array}$ \\
\hline $\begin{array}{l}\text { Number of } \\
\text { observations }\end{array}$ & 135 & 138 & 138 & 138 & 138 & 138 & 138 & 138 & 138 & 138 \\
\hline Centered $R^{2}$ & 0.3132 & 0.4913 & 0.5117 & 0.5280 & 0.5426 & 0.5368 & 0.4907 & 0.2481 & 0.2418 & 0.5097 \\
\hline
\end{tabular}

$*$ Significant at the 1 or 5 percent level.

Note: The dependent variable is the decile mean income/overall mean income. Numbers in parentheses are $p$-values. Openness and government expenditure as share of GDP are instrumented. GMM calculations are performed using the ivreg2.ado routine developed by Baum and others (2002). A suffix of 5 indicates a fiveyear average. Government expenditures, openness, and M2 are expressed as a share of GDP (such as 0.3 not 30 percent); DFI/GDP is expressed as a percentage. Real rate of interest is expressed as an annual percentage. Mean income is expressed in 1995 pPp dollars. Regressions are run with robust standard errors.

Source: Author's computations based on household survey data from the WYD. 
FiguRE 2. Different Measures of Openness for China, 1980-2000

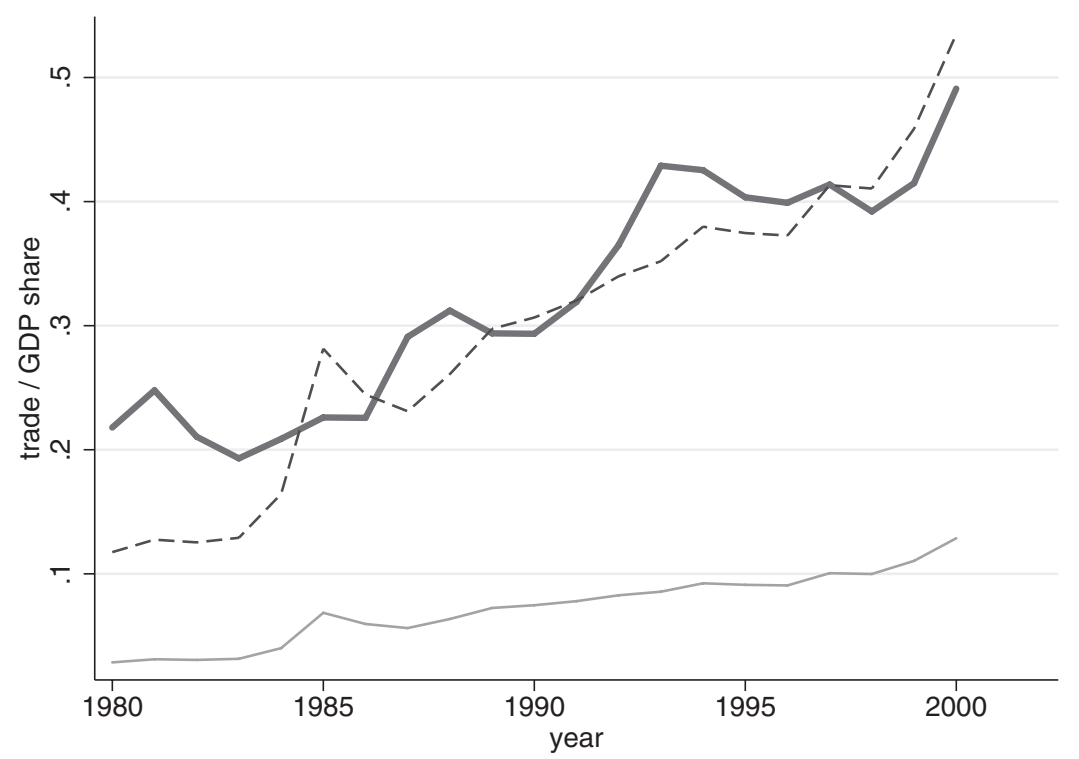

Source: For the Dollar-Kraay measure, author's calculations based on Penn World Table 6.1; for the trade to GDP ratio in current prices, author's calculations based on World Bank data (World Development Indicators and Statistical Information Management and Analysis database); for the trade to GDP ratio in constant prices, the volume of trade is from Penn World Table 6.1 (the variable Kopen).

The key question is, which approach makes more sense? When the relationship of interest is how important international trade is for income creation and income distribution in a given country, it is the trade to GDP ratio in nominal prices that matters. The role that trade plays in the total income of a countryin people's earnings-depends on how much actual income is generated in trade compared with purely domestic activities. Income distribution is affected by the incomes actually received, not by notional incomes that are ascribed through the imputation of international prices to domestic goods and services. For a barber in India, for example, what matters for his income and for the income distribution in India is the actual local pay received, not how much his output is valued at international prices. For China, surely exports play a role in people's income that is commensurate with the 26 percent share of exports in nominal GDP in 2000, rather than with the 7 percent that exports represent in China's GDP calculated in PPP terms. ${ }^{26}$

26. Clearly the greater the PPP value of GDP, the better off the average citizen, who can consume more goods and services. This type of PPP comparison is useful for comparing average welfare levels in different countries. But this is not the objective here. 
Figure 3. Different Measures of Openness for India, 1980-2000

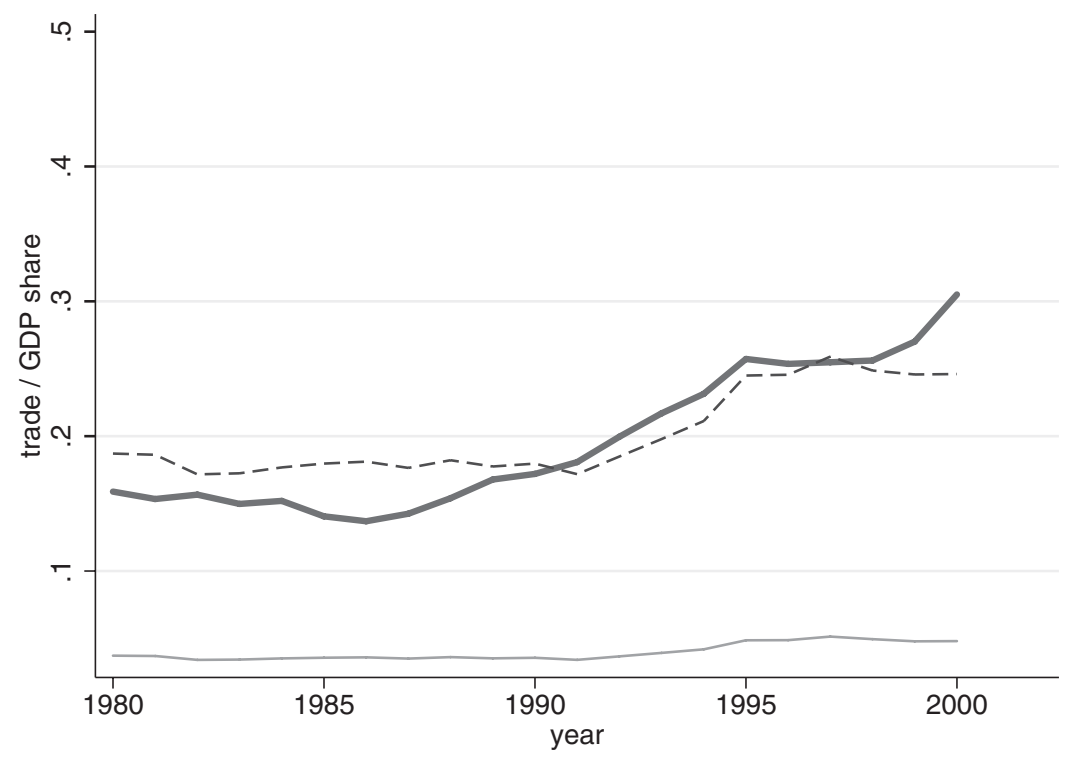

Source: For the Dollar-Kraay measure, author's calculations based on Penn World Table 6.1; for the trade to GDP ratio in current prices, author's calculations based on World Bank data (World Development Indicators and Statistical Information Management and Analysis database); for the trade to GDP ratio in constant prices, the volume of trade is from Penn World Table 6.1 (the variable kopen).

In conclusion, the results of the level regressions (to the extent that most of the identification comes from cross-sectional differences) show that rich people in poor countries that trade more tend to control a greater share of overall income than the rich people in equally poor countries that trade less. However, at some rather high level of mean country income-around PPP\$8,000 per capita as calculated from household surveys-the situation reverses and more open countries are associated with more equal income distribution (higher income shares for the poor).

\section{Conclusion}

The effects of globalization on income distribution within rich and poor countries are a matter of intense debate. This study examined these effects using new data from household surveys and looking at the impact of openness (trade as a share of GDP) and direct foreign investment (as a percentage of GDP) on the entire income distribution in both poor, middle-income, and rich countries. It found rather robust evidence that in countries at very low income level, it is the rich who benefit from openness, but as income levels rise, the incomes of the poor and the middle class rise proportionately more than the incomes of the rich. 
Because most of the identification comes from cross-country variability, it cannot be strongly asserted that for any given country, openness makes income distribution worse before making it better, but it can be argued that the poor in poor countries do not seem to be the beneficiaries from greater trade. In other words, in poor countries that are otherwise identical, the income shares of the poor will be less in countries that trade more than in countries that trade less.

Direct foreign investment has no effect on income distribution. Democracy raises the income shares of the middle deciles and leaves those of the top and the bottom deciles unchanged (possibly explaining why synthetic measures of inequality such as the Gini coefficient have generally failed to detect an effect of democracy on inequality). Government expenditures increase the income shares of the bottom income groups, and higher real rates of interest-a topic attracting surprisingly little attention-and inflation are prorich. Even the middle classes lose income shares when real interest rates and inflation are high. The use of a trade to GDP ratio in PPP terms is shown to be misleading in studies of the effect of trade on income distribution.

In conclusion, the poorest deciles in poor countries-those who should benefit most from increased trade according to both economic theory and the policy prescriptions of international organizations-appear to be the losers in relative terms. The case for trade as an engine of growth for the poorest of the poor is not completely undermined, however. But the case must be based on trade's impact on average incomes which, if sufficient, might lift the real incomes of the poor as well as those of the rich. The case cannot be made on the basis of trade's favorable or neutral impact on income distribution.

\section{REFERENCES}

Arbache, Jorge Saba. 1999. "How Do Economic Reforms Affect the Dispersion and Structure of Wages? The Case of an Industrialising Country Labor Market.” Paper presented at the 1999 Royal Economic Society conference, March 29-April 1, University of Nottingham, U.K.

Baldwin, Richard E., and Philippe Martin. 1999. "Two Waves of Globalization: Superficial Similarities, Fundamental Differences.” NBER Working Paper 6904. National Bureau of Economic Research. Cambridge, Mass.

Barro, Robert. 2000. "Inequality and Growth in a Panel of Countries." Journal of Economic Growth $5(1): 5-32$.

Baum, C. F., M. E. Schaffer, and S. Stillman. 2002. "Instrumental Variables and GMM: Estimation and Testing.” Working Paper 545. Boston College, Department of Economics, Chestnut Hill, Mass. Available online at http://fmwww.bc.edu/ec-p/WP545.pdf.

Beck, T., G. Clarke, A. Groff, P. Keefer, and P. Walsh. 2000. "New Tools and New Tests in Comparative Political Economy: The Database of Political Institutions.” Policy Research Working Paper 2283. World Bank, Washington, D.C.

Behrman, Jere, Nancy Birdsall, and Miguel Szekely. 2003. "Economic Policy and Wage Differentials in Latin America." Center for Global Development Working Paper 29. Washington, D.C. Available online at www.cgdev.org/publications/? pubid $=29$.

Benarroch, Michael, and James D. Gaisford. 1997. "Economies of Scale, International Capital Mobility, and North-South Inequality." Review of International Economics 5(3):412-28. 
Beyer, Harald, Patricio Rojas, and Rodrigo Vergara. 1999. "Trade Liberalization and Wage Inequality." Journal of Development Economics 59(1):103-23.

Birdsall, Nancy, and Amar Hamoudi. 2002. "Commodity Dependence, Trade and Growth: When Openness Is Not Enough.” Center for Global Development Working Paper 7. Washington, D.C. Available online at www.cgdev.org/publications/? pubid $=7$.

Birdsall, Nancy, and Juan Luis Londono. 1997. “Asset Inequality Matter: An Assessment of the World Bank's Approach to Poverty Reduction.” American Economic Review 87(2):32-37.

. 1998. "No Trade-off: Efficient Growth via More Equal Human Capital Accumulation.” In Nancy Birdsall, Carol Graham, and Richard Sobot, eds., Beyond Tradeoffs: Market Reforms and Equitable Growth in Latin America. Washington, D.C.: Inter-American Development Bank and Brookings Institution.

Bollen, K., and R. W. Jackman. 1985. "Political Democracy and the Size Distribution of Income." American Sociological Review 50:438-57.

Bordo, Michael D., Barry Eichengreen, and Douglas A. Irwin. 1999. "Is Globalization Today Really Different than Globalization a Hundred Years Ago?” NBER Working Paper W7195. National Bureau of Economic Research, Cambridge, Mass.

Cornia, Andrea, and Sampsa Kiiski. 2002. "Trends in Income Distribution in the Post World War II Period: Evidence and Interpretation.” WIDER Working Paper 2001/89. United Nations University, World Institute for Development Economics Research, Helsinki. Available online at www.wider. unu.edu/publications/dps/dp2001-89.pdf.

Craft, Nicholas. 2000. "Globalization and Growth in the Twentieth Century." Background paper to World Economic Outlook. International Monetary Fund. Washington, D.C.

Deininger, Klaus, and Lyn Squire. 1997. "Deininger and Squire Data Set: A New Data Set Measuring Income Inequality.” World Bank, Washington, D.C. Available online at www.worldbank.org/ research/growth/dddeisqu.htm.

Dluhosch, Barbara. 1998. “Globalization and European Labor Markets.” CEPR Discussion Paper 1992. Centre for Economic Policy Research, London.

Dollar, David, and Aart Kraay. 2000. "Growth Is Good for the Poor.” World Bank, Development Research Group, Washington, D.C.

2001. “Trade, Growth, and Poverty.” Policy Research Working Paper 2615. World Bank, Washington, D.C.

- 2002. "Growth Is Good for the Poor." Journal of Economic Growth 7(3):195-225.

Fields, Gary. 2001. Distribution and Development: A New Look at the Developing World. New York: Russell Sage Foundation and Cambridge, Mass.: MIT Press.

Freeman, Richard B. 1995. "Are Your Wages Set in Beijing?” Journal of Economic Perspectives 9(3):15-32.

Galbraith, James K., and Hyunsub Kum. 2002. "Inequality and Economic Growth: Data Comparisons and Econometric Tests." University of Texas, LBJ School of Public Affairs, University of Texas Inequality Project, Austin.

Gradstein, Mark, and Branko Milanovic. 2004. "Does Liberté=Egalité? A Survey of the Empirical Evidence on the Links between Political Democracy and Income Inequality.” Journal of Economic Surveys 18(4):515-37.

Gradstein, Mark, Branko Milanovic, and Yvonne Ying. 2001. "Democracy and Income Inequality: An Empirical Analysis.” Policy Research Working Paper 2561. World Bank, Washington, D.C.

Harrison, Ann, and Gordon Hanson. 1999. "Who Gains from Trade Reform? Some Remaining Puzzles." Journal of Development Economics 59(1):125-54.

Higgins, Matthew, and Jeffrey Williamson. 1999. "Explaining Inequality the World Round: Cohort Size, Kuznets Curve, and Openness.” Federal Reserve Bank of New York Working Paper 79. Available online at www.ssrn.com.

IMF (International Monetary Fund). Various years. International Financial Statistics. Washington, D.C. 
Kanbur, Ravi. 2000. "Income Distribution and Development." In A. B. Atkinson and F. Bourguignon, eds., Handbook of Income Distribution, vol. 1. Amsterdam: North Holland-Elsevier.

Kremer, Mark, and Eric Maskin. 2003. “Globalization and Inequality.” Harvard University, Department of Economics, Cambridge, Mass. Available online at http://post.economics.harvard.edu/faculty/ kremer/webpapers.

Lejour, Arjan M., and Paul J. G. Tang. 1999. "The Differential Impact of the South on Wage Inequality in the North.” СРв Netherlands Bureau for Economic Policy Analysis, The Hague.

Li, Hongyi, Lyn Squire, and Heng-fu Zou. 1998. "Explaining International and Intertemporal Variations in Income Inequality.” Economic Journal 108(446):26-43.

Lubker, Malte, Graham Smith, and John Weeks. 2002. "Growth and the Poor: A Comment on Dollar and Kraay." Journal of International Development 14:555-71.

Lundberg, Mattias, and Lyn Squire. 1999. "Growth and Inequality: Extracting the Lessons for Policymakers.” World Bank, Washington, D.C.

- 2003. "The Simultaneous Evolution of Growth and Inequality." Economic Journal 113(487):326-44.

Lustig, Nora, and Ravi Kanbur. 1999. "Why Is Inequality Back on the Agenda?” Paper prepared for the Annual World Bank Conference on Development Economics, April 28-30, World Bank, Washington, D.C. Available online at www.worldbank.org/poverty/wdrpoverty/inequality.htm.

Melchior, Arne, Kjetil Telle, and Henrik Wiig. 2000. "Globalisation and Inequality: World Income Distribution and Living Standards, 1960-1998." Studies on Foreign Policy Issues Report 6B:2000. Royal Norwegian Ministry of Foreign Affairs, Oslo.

Milanovic, Branko. 1994. "Determinants of Cross-Country Income Inequality: An Augmented Kuznets' Hypothesis.” Policy Research Working Paper 1246. World Bank, Washington, D.C.

—. 2000. "The Median Voter Hypothesis, Income Inequality and Income Redistribution: An Empirical Test with the Required Data.” European Journal of Political Economy 16(3):367-410.

—. 2002. "True World Income Distribution, 1988 and 1993: First Calculation Based on Household Surveys Alone.” Economic Journal 112(476):51-92.

- 2004. Worlds Apart: Global and International Inequality 1950-2000. Princeton, N.J.: Princeton University Press.

Milanovic, Branko, and Shlomo Yitzhaki. 2002. "Decomposing World Income Distribution: Does the World Have a Middle Class?" Review of Income and Wealth 48(2):155-78.

Ravallion, Martin. 2001. "Growth, Inequality, and Poverty: Looking beyond Averages.” World Development 29(11):1803-15.

2004. "Loking beyond Averages in the Trade and Poverty Debate." Policy Research Working Paper 3461. World Bank, Washington, D.C.

Robertson, Raymond. 2000. "Trade Liberalisation and Wage Inequality: Lessons from the Mexican Experience.” World Economy 23(6):827-49.

Rodrik, Dani. 2000. “Comments on 'Trade, Growth, and Poverty’ by D. Dollar and A. Kraay.” Harvard University, John F. Kennedy School of Government, Cambridge, Mass. Available online at http:// ksghome.harvard.edu/ .drodrik.academic.ksg.

Sala-i-Martin, Xavier. 2002. “The Disturbing 'Rise' of World Income Inequality.” NBER Working Paper 8904. National Bureau of Economic Research, Cambridge, Mass.

Schott, Peter K. 1999. “One Size Fits All? Heckscher-Ohlin Specialization in Global Production.” NBER Working Paper 8244. National Bureau of Economic Research, Cambridge, Mass.

Schultz, T. P. 1998. "Inequality in the Distribution of Personal Income in the World: How It Is Changing and Why." Journal of Population Economics 11(3):307-44.

Slaughter, Matthew J., and Phillip Swagel. 1997. "The Effect of Globalization on Wages in the Advanced Economies.” International Monetary Fund Staff Studies for World Economic Outlook. Washington, D.C.

Spilimbergo, Antonio, Juan Luis Londono, and Miguel Szekely. 1999. "Income Distribution, Factor Endowment and Trade Openness." Journal of Development Economics 59(1):77-101. 
Tang, Paul J. G., and Adrian Wood. 1999. "Globalisation, Co-Operation Costs and Wage Inequalities." Online document available at http://ssrn.com/abstract $=148169$.

Tavares, Jose, and Romain Wacziarg. 2001. "How Democracy Affects Growth.” European Economic Review 45(8):1341-78.

UNCTAD (United Nations Conference on Trade and Development). 1996. Handbook of International Trade and Development Statistics. Geneva.

1997. Handbook of International Trade and Development Statistics. Geneva

2000. Handbook of International Trade and Development Statistics. Geneva

WIDER (United Nationa University, World Institute for Development Economics Research). 2004. World Income Inequality Database. Available online at ww.wider.unu.edu/wiid/wiid.html.

Williamson, Jeffrey G. 1996. "Globalization and Inequality Then and Now: The Late 19th and Late 20th Centuries Compared.” NBER Working Paper 5491. National Bureau of Economic Research, Cambridge, Mass.

Winters, Alan, Neil McCulloch, and Andrew McKay. 2004. "Trade Liberalization and Poverty: Evidence so Far." Journal of Economic Literature 42(1):72-115.

Wood, Adrian. 1994. North-South Trade, Employment and Inequality: Changing Fortunes in a SkillDriven World. Oxford: Clarendon Press.

- 2000. "Globalisation and Wage Inequality: A Synthesis of Three Theories.” Department for International Development, U.K. Available online at www.ssrn.com.

World Bank. Various years. World Development Indicators. Washington, D.C. 